\title{
Proses Kreatif Dalam Penciptaan Lagu Bersumber Visi Misi Kabupaten
}

\author{
Mohamad Yusuf Wiradiredja \\ Institut Seni Budaya Indonesia (ISBI) Bandung \\ Jl. Buahbatu No. 212 Bandung
}

\begin{abstract}
Source of Inspiration for the art creators come from a variety of things, including of a formal challenge in vision-mission had characteristic abstract, visionary, and formal. These challenges is the pressure which requires the artist to explore all their ability to form a song that has been limited by resources of creation. The song which contains the spirit of the vision-mission should then be internalized into the social reality in society, grounded, and operationally effectively convey the intent and purpose of the lyrical content of the song that contains vision-mission. In product textually, the musicality of song are required of people's identity which is historically and culturally Sunda. The creative process is referential from the idea of the work which in this case is a visioning. The song "Bandung Barat Cermat" is the product between the idea and experience of art creators, ultimately the creative process becomes interesting because they have to bring propaganda, community culture, and experience art creators. This result research is a description of the analysis of creative process of the musical song titled "Bandung Barat Cermat".
\end{abstract}

Keywords: vision-mission, songs, creative process, musicality

\begin{abstract}
ABSTRAK
Sumber inspirasi bagi kreator seni bisa datang dari berbagai macam hal, termasuk dari sebuah tantangan formal dalam mengobjektivikasi sebuah visi misi yang bersifat abstrak, visioner, dan formal (kaku). Pada titik tertentu tantangan tersebut merupakan tekanan (press) yang menuntut seniman untuk mengeluarkan segenap kemampuannya dalam mengeksplorasi sebuah karya lagu yang telah dibatasi oleh sumber-sumber penciptaan. Tidak berhenti sampai menjadi sebuah karya jadi, lagu yang memuat roh visi-misi kemudian harus diinternalisasikan menjadi realitas sosial di masyarakat, membumi, dan secara operasional efektif menyampaikan maksud dan tujuan dari isi lirik lagu yang memuat visi misi tersebut. Secara tekstual kekaryaan, musikalitas dari karya lagu ini, dituntut untuk tidak keluar dari identitas masyarakat, yang secara historis dan terutama kultural identik dengan masyarakat Sunda. Pada titik ini, proses kreatif secara referensial tidak akan lepas dari gagasan karya yang dalam hal ini adalah sebuah visioning. Lagu "Bandung Barat Cermat" adalah produk dari pertemuan antara gagasan karya dan pengalaman seni kreator, akhirnya proses kreatif menjadi menarik karena harus mempertemukan 'kebutuhan propaganda', kultur masyarakat, dan pengalaman seni kreator. Hasil penelitian ini merupakan deskripsi dari analisis proses kreatif terhadap karya musikalitas lagu berjudul "Bandung Barat Cermat".
\end{abstract}

Kata kunci: visi-misi, karya lagu, proses kreatif, musikalitas 


\section{PENDAHULUAN}

Tantangan kreativitas bagi seniman bisa datang dari berbagai hal, di saat yang bersamaan tantangan tersebut bisa jadi merupakan sumber inspirasi. Tantangan, bagi setiap subjek kreatif bisa saja dimaknai sebagai tekanan, di mana tekanan menurut Rhodes dalam Utami Munandar merupakan salah satu unsur penting dalam kreativitas bersama pribadi, proses, dan produk (2009:20). Salah satu tantangan dalam berkreativitas adalah melakukan sebuah transformasi bentuk dari sebuah gagasan yang bersifat ideal (abstrak) menjadi bersifat praktis dan operasional. Seperti halnya ketika salah satu kabupaten di Jawa Barat memberikan tantangan tentang bagaimana sebuah "visi-misi" pemerintah dapat secara efektif dikenali, diketahui, dan diimplementasikan bersama secara sinergis antara pemerintah dan masyarakatnya?

Tantangan tersebut datang dari pemerintah kabupaten Bandung Barat yang memiliki visi dan misi tentang masyarakat yang secara sederhana diwakili oleh kata "cerdas", "rasional", "maju", "agamais", dan "sehat" dengan akronim Bandung Barat "Cermat". Bandung Barat sendiri merupakan wilayah kabupaten yang relatif baru di Provinsi Jawa Barat, diinisiasi sejak tahun 1999 oleh tokoh-tokoh masyarakat kemudian dideklarasikan sebagai kabupaten pada bulan Agustus tahun 2003, dan akhirnya secara resmi berdasarkan UU No.12 tahun 2007, Bandung Barat kemudian menjadi kabupaten tersendiri yang merupakan hasil pemekaran dari kabupaten Bandung. Bupati pertama yang menduduki roda pemerintahan adalah Drs. $\mathrm{H}$. Abu Bakar, M.Si yang terpilih melalui pemilihan langsung selama dua periode berturut-turut sejak tahun 2008 hingga saat ini setelah sebelumnya (2007) diisi oleh Bupati sementara.

Sebagaimana diketahui, dalam sebuah organisasi, baik di lingkungan pemerintahan maupun organisasi kemasyarakatan visi-misi merupakan mapping point sekaligus fondasi penting terkait ke mana arah roda pemerintahan tertentu akan dibawa. Harapan dengan adanya visi sebuah organisasi, adalah semata-mata untuk menjadi bahan rujukan dalam memandang jauh ke depan tentang apa yang akan dan apa yang harus dicapai sesuai dengan target capaian organisasinya, yang tentu saja semua itu tidak akan berarti apa-apa, apabila masyarakat sebagai sasaran sekaligus pelaku utama bersama pemerintah tidak memahami dan merasa memiliki pandangan bersama. Hal tersebut tidak terkecuali dengan kabupaten Bandung Barat, sebagai wilayah baru visimisi pemerintah kemudian dicanangkan dan disosialisasikan guna mendapat dukungan langsung dari segenap masyarakat di kabupaten Bandung Barat.

Sebagaimana sifat dari visioning, visimisi pemerintah bersifat abstrak dan ideal, sulit diterjemahkan dan dimengerti, akibatnya dalam kontek implementasi kurang didukung penuh oleh masyarakat sebagai pelaku sekaligus sebagai sasaran utama, hal tersebut tidak terlepas dari inklusifitas visi dan misi yang cenderung abstrak (tidak membumi), tidak diinternalisasi dan diobjektifikasi menjadi bagian dari masyarakat itu sendiri, dengan kata lain visivisi pemerintah tidak menjadi bagian dari budaya masyarakat itu sendiri. Dalam konteks tesebut visi-misi secara terbatas hanya milik pemerintah, yang secara kultural tidak dilegitimasi eksistensinya oleh anggota masyarakat, sebagaimana Peter L. Berger (2013:126) menyatakan bahwa legitimasi berfungsi untuk membuat objektifikasi tingkat pertama, legitimasi adalah pengetahuan yang diobjektivikasi secara sosial yang bertindak untuk menjelaskan dan membenarkan tatanan sosial. Dengan demikian, dalam konteks ini visimisi pemerintah yang bersifat ideal hingga 
operasional harus dilegitimasi/diakui dijalankan secara kultural oleh masyarakat itu sendiri. Pada titik ini, visi-misi pemerintah penting untuk diterapkan secara kultural yang salah satunya melalui seni tradisi yang telah menyatu dengan manusia sebagai pelaku utama. Tulisan ini merupakan sebuah deskripsi dari analisis tentang proses kreatif dan bagaimana sebuah karya seni dapat lahir dari sebuah hal yang bersifat abstrak dan diekspresikan untuk menjadi nyata dan operasional. Secara khusus, tulisan ini menitikberatkan pada analisis terhadap proses kreatif dari karya lagu berjudul "Bandung Barat Cermat", bagaimana lagu ini dibuat, unsur musikal apa saja yang dihadirkan agar dengan mudah diinternalisasi oleh pendengarnya, dan bagaimana pengalaman kesenimanan kreator mempengaruhinya.

\section{METODE}

Karya "Bandung Barat Cermat" merupakan karya seni yang tidak lahir begitu saja tanpa diawali dengan sebuah proses, sebagaimana disampaikan sebelumnya, sekurang-kurangnya terdapat tiga unsur penting terciptanya karya lagu "Bandung Barat Cermat". Ketiga unsur tersebut adalah; gagasan, kreator dan karya itu sendiri. Gagasan dalam konteks di luar seniman adalah tantangan konversi dari sebuah visi-misi menjadi sebuah karya seni, gagasan juga dalam hal ini secara internal (seniman) merupakan bagaimana perspektif seniman dalam melihat tantangan. Gagasan internal bergantung pada subjektivitas seniman, maka dari itu latar belakang pengalaman kesenimanan, dan proses panjang apresiasi seorang seniman sangat berpengarus terhadap karya itu sendiri. Kemudian yang terakhir adalah karya yang merupakan produk jadi sebagai materi. Berdasarkan kenyataan tersebut, kajian dalam tulisan ini menitikberatkan metode terhadap kajian tekstual musikalitas, dan historis (dalam batas tertentu terhadap pengalaman musikal). Metode analisis menitik beratkan pada kajian terhadap unsur musikal, sehingga fokus pembahasan akan menitikberatkan pada gagasan karya (dari visioning menjadi karya lagu) dan unsur musikal karya.

\section{HASIL DAN PEMBAHASAN}

\section{Tantangan Kreativitas}

SVisi dan misi Bandung Barat pada periode kepemimpinan bupati Drs. H. Abu Bakar, M.Si adalah "CERMAT". Visi misi tersebut merupakan akronim dari cerdas, rasional, maju agamais, dan sehat. Target capaian cerdas adalah diharapkan masyarakat Bandung Barat mempunyai sikap positif serta seimbang menyatukan antara pikiran dan perasaannya dalam menyikapi kehidupan di lingkungannya. Kemudian, capaian dari rasional adalah diharapkan masyarakat Bandung Barat mempunyai pola pikir yang proporsional dalam menyikapi berbagai permasalahan hidupnya. Kemudian target capaian visi maju adalah diharapkan masyarakat Bandung Barat tidak boleh tertinggal oleh daerah lainnya dalam segala bidang. Adapun target capaian Agamais adalah diharapkan masyarakat Bandung Barat dalam menjalani kehidupannya harus berpedoman pada nilai-nilai agama, sehingga diharapkan masyarakatnya beriman serta taqwa kepada Tuhan Yang Maha Esa. Selanjutnya target capaian dari visi sehat adalah diharapkan masyarakat Bandung barat sehat, baik lahir maupun batinnya. Oleh karena itu, visi serta misi tersebut merupakan sebuah cita-cita yang diharapkan oleh pemerintah kabupaten Bandung Barat dan masyarakatnya untuk mencapai keadilan serta kesejahteraan.

Untuk mewujudkan visi serta misi Kabupaten Bandung Barat, sudah dipastikan 
memerlukan sebuah usaha serta kerja keras dari berbagai pihak, baik unsur pemerintahan maupun masyarakatnya. Adapun permasalahan yang akan terkait dengan hal ini, bagaimanakah konsep untuk mewujudkan sosialisasi visi misi setiap Pemerintah Daerah di Jawa Barat, yang dipandang efektif dan efisien? Pertanyaan tersebut bertolak dari beberapa permasalahan yang penulis amati selama ini; pertama, pada umumnya hampir setiap kabupaten maupun kota, pendekatannya hanya sebatas struktur formal saja dalam rangka sosialisasi masing-masing visi serta misinya. Artinya, pendekatan sosialisasinya hanya sebatas di lingkungan masing-masing instansinya secara formal seremonial. Begitu pula, termasuk Kabupaten Bandung Barat belum menampakkan pendekatan yang efektif di samping pendekatan struktur formal. Padahal, visi dan misi yang dirumuskan oleh setiap instansi tersebut, harus mempunyai dampak yang lebih luas, oleh karena yang akan melaksanakan visi misi tersebut adalah masyarakatnya sendiri. Kemudian kedua, permasalahan yang terkait dengan muatan visi dan misi masing-masing instansi dipandang kurang mengakar kepada nilai-nilai budayanya. Sebagai salah satu contoh umumnya dalam sosialisasi masing-masing visi dan misi, maupun mottonya tersebut, masih dipandang belum mencerminkan nilai-nilai kearifan lokal, yang ada hanya sebatas singkatan-singkatan yang kurang terukur seperti telah disebutkan di atas. Berkaitan dengn hal tersebut, apabila masing-masing instansi di daerah di lingkungan Propinsi Jawa Barat kurang peka terhadap pentingnya penerapan nilainilai budayanya sebagai kearifan lokal, dihawatirkan masyarakat akan kehilangan identitas keperibadian bangsanya. Pada titik ini, pendekatan budaya yang secara operasional dilakukan dengan pendekatan seni penting untuk dilakukan.

Seperti telah disinggung di atas, salah satu strategi khususnya dalam sosialisasi visi misi Bandung Barat adalah dengan pendekatan budaya lokal yang mengandung unsur bahasa daerah dan seni. Mengapa demikian, karena melalui seni budaya lokal apabila dilihat dari geopolitiknya akan mengakar kepada nilai sosial budaya setempat, yang telah melahirkan nilai-nilai kearifan lokal yang telah turun temurun sejak lama. Salah satu bentuk kearifan lokal dapat digali melalui pendekatan serta pemanfaatan bahasa daerah dan kesenian Sunda. Kedua aspek ini merupakan sebuah kekuatan seni budaya masyarakat Sunda khususnya di lingkungan Bandung Barat. Mengingat hal tersebut di atas, pemerintah daerah Propinsi Jawa Barat merumuskan sebagai landasan hukum dalam rangka pelestarian bahasa daerah dan kesenian dalam Perda No. 5 dan 6.

Pada konteks proses kreatif, kreator tidak cukup hanya dengan menggunakan pertimbangan nilai estetis dan idealisme seniman. Tantangan bagi penulis pada titik ini adalah harus mampu melakukan harmoni antara idealitas visi-misi dan estetika karya yang harus tetap indah, dapat dinikmati, serta mudah dimainkan oleh masyarakat umum. Dengan kata lain, kreator harus berkarya berdasarkan rambu-rambu atau bahan yang sudah ada dan tersedia, Jakob Sumardjo (2000:80-81) juga menjelaskan bahwa kreativitas juga bertolak dari yang sudah ada, dari kebudayaan, dan tradisi.

Tantangan kreativitas selain mengedepankan unsur keindahan (estetis) penting bagi kreator untuk dapat tetap berada pada jalur utama yakni menjadikan karya kreatif ini sebagai sesuatu yang real dari visi-misi Bandung Barat. Tujuan utama dari karya seni yang diciptakan ini adalah dalam rangka sosialisasi visi dan misi Bandung Barat untuk: pertama mempercepat pengertian serta pemahaman masyarakat tentang substansi visi misi Kabupaten Bandung Barat; kedua menumbuhkan semangat untuk bersama-sama merealisasikan visi serta misinya. Adapun harapan yang ingin dicapai melalui 
sosialisasi visi dan misi Kabupaten Bandung Barat adalah, pertama adanya kesadaran akan pentingnya arti serta makna nilai-nilai budaya yang sarat dengan filosofis, sehingga masyarakat Bandung Barat akan lebih menyadari akan pentingnya nilai-nilai kepribadian bangsa. Kedua, secara khusus sosialisi visi dan misi Kabupaten Bandung Barat cermat jilid dua akan cepat tercapai secara efektif dan efisien. Pada titik ini, penulis sebagai kreator dituntut untuk membuat karya yang dalam konteks tertentu dibatasi oleh frame visi-misi yang memberikan batasan, sekaligus kerangka utama karya.

Dalam karya ini, terdapat dua unsur penting yang menjadi fondasi utama di antaranya sastra lagu, dan eksplorasi teks musikal. Sastra lagu dalam karya ini dibuat sangat sederhana dengan diksi sesuai dengan kerangka visi-misi Bandung Barat yang "Cerdas". Pemilihan diksi yang sederhana tersebut pada konteks tertentu membutuhkan pertimbangan yang matang, terutama berkaitan dengan penggunaan fonem yang juga menentukan estetika lagu. Unsur kedua adalah teks musikal, visi-misi dalam karya lagu ini selain harus diakomodasi melalui sastra lagu, tentu saja juga harus dapat diekspresikan dengan indah, penuh semangat dan mudah dicerna dan dilagukan oleh masyarakat, di samping itu identitas musikal masyarakat Sunda tetap harus dominan. Maka stuktur dan pola lagam lagu dieksplorasi dengan menggunakan idiom-idiom identitas musik Sunda. Pada karya ini, Tembang Sunda Cianjuran atau mamaos sebagai genre dalam khazanah musik Sunda dijadikan referensi utama pembuatan karya.

\section{Proses Penciptaan}

Proses penciptaan suatu karya tidak dapat terlepas dari ide kekaryaan, referensi karya, dan bentuk karya itu sendiri, berikut ini adalah sebuah tahapan dalam proses produksi suatu karya seni dengan melewati dimensi: (1) gagasan penciptaan; (2) Sumber Penciptaan; dan (3) Bentuk Penciptaan.

\section{Gagasan Penciptaan}

Untuk mewujudkan karya seni Sunda dalam rangka sosialisasi visi dan misi Bandung Barat tersebut, tidak akan lepas dari gagasan penciptaan yang betumpu dari permasalahan yang ada. Seperti telah dijelaskan, pada umumnya ada beberapa permasalahan terkait dengan teknis sosialisasi yang kurang efektif dari masing-masing visi dan misi di setiap instansi, baik kabupaten maupun kota di lingkungan Provinsi Jawa Barat. Dari beberapa permasalahan tersebut dapat disimpulkan bahwa inti masalah yang mendasar dalam rangka sosialisasi visi dan misi masing kabupaten serta kota tersebut adalah rendahnya strategi untuk mengedukasi nilai-nilai seni budaya kepada masyarakat agar tidak terserabut dari akar budayanya. Di samping itu, apapun bentuk visi dan misinya secara substansi beberapa instansi terkadang terlalu mengedepankan pada kepentingan formal semata, sementara nilai seni budaya sebagai aspek yang cukup penting terabaikan. Oleh karena itu, pemerintah Kabupaten Bandung Barat nampaknya menyadari akan arti pentingnya mengangkat nilai-nilai seni budaya lokal. Seperti telah dijelaskan, aspek seni budaya dapat dijadikan piranti sekaligus sebagai media untuk mengedukasi masyarakatnya, khusunya dalam rangka sosialisasi visi dan misi pemerintah daerahnya. Salah satu strategi sosialisasi visi misi Bandung Barat melaui seni budaya adalah mengkemas bentuk seni melalui kreativitas penuh dengan inovasi, sehingga diharapkan masyarakat Bandung Barat akan lebih mudah memahaminya. Setelah masyarakat dapat memahaminya diharapkan mereka dapat merasakan serta adanya kesadaran betapa pentingnya untuk mewujudkan visi dan misi Bandung Barat, sehingga mereka akan lebih meningkat nilai partisipasinya secara bersama-sama dalam 
mewujudkan visi misi pemerintah daerahnya tersebut.

\section{Sumber Penciptaan}

Untuk merealisasikan sebuah karya seni sudah dapat dipastikan salah satu unsur yang sangat penting adalah tersedianya sumber penciptaan yang akan dijadikan bahan kreativitas yang dalam hal ini untuk mewujudkan produk seni musik. Melalui penguasaan serta memahami sumber-sumber penciptaan diharapkan akan lebih memperkaya referensi dalam mewujudkan sebuah karya seni untuk mencapai nilai optimal. Oleh karena wujud musikal yang dibangun berbentuk musik dan lagu Sunda, maka idiom yang cukup dominan digunakan bertumpu pada sumber musikalitas Sunda. Namun demikian, di samping itu untuk lebih memperkaya musikalitas, karya tersebut juga ditunjang oleh unsur musikalitas lainnya. Dengan harapan akan lebih tampak nilai kontekstualitasnya dengan perkembangan zaman saat ini. Oleh karena itu, secara garis besarnya sumber musikal terbagi atas; (a) Tembang Sunda; (b) Kawih Sunda) dan (c) Ideom Musik Barat.

\section{a. Tembang Sunda}

Sebagai salah satu bagian dari wilayah daerah propinsi di Indonesia, Jawa Barat cukup potensial akan ragam jenis kesenian di antaranya adalah tembang Sunda. Dilihat dari segi fungsi dan kedudukannya tembang Sunda tersebut, dipandang signifikan di lingkungan masyarakat Jawa Barat. Secara faktual fungsi tembang Sunda di samping untuk hiburan, dan upacara, juga untuk pendidikan. Masih fungsionalnya tembang Sunda di lingkungan masyarakat Jawa Barat, menjadikan kedudukan tembang yang disebut mamaos ini memiliki pengaruh yang signifikan terhadap identitas dalam konteks seni budaya Sunda, sehingga seni tersebut dapat dijadikan salah satu identitas masyarakatnya. Oleh karena itu, penulis memasukkan tembang Sunda sebagai salah satu sumber penciptaan dalam mewujudkan karya ini.

Beberapa unsur yang penulis jadikan sumber penciptaan di antaranya kontur melodi, dan ornamentasi. Unsur melodi dan ornamentasi walaupun tidak terlalu dominan, namun secara langsung maupun tidak langsung telah memberikan nuansa musikal yang signifikan terutama pada bagian kontur melodi untuk kebutuhan lirik yang menekankan pada beberapa bagian yang dipandang penting. Misalnya melalui pemanfaatan melodi dan ornamentasi tembang Sunda membangun nuansa lebih impresif untuk memberikan nuansa dalam menyampaikan pesan lirik visi dan misi terhadap pendengarnya.

\section{b. Kawih Sunda}

Menurut pengertian karawitan Sunda, yang dimaksud dengan kawih adalah lagulagu yang berirama tetap (metris). Adapun bentuk dari jenis seni kawih tersebut di Sunda relatif cukup banyak seperti, kawih kapasindenan, wanda anyar, jenaka sunda, kawih barudak, dan sebagainya. Keberadaan kawih dilihat dari perspektif historisnya sudah begitu lama ada di lingkungan masyarakat Sunda. Hal tersebut, berdasar dari salah satu referensi dari salah satu buku kuno yakni Siskakanda ng Karesian abad ke 16, yang telah menyebut-nyebut istilah kata kawih, sebaliknya istilah tembang tidak disebutkan. Oleh karena itu, dapat disimpulkan bahwa keberadaan kawih lebih lama serta mengakar khususnya di masyarakat Sunda.

Keterkaitannya dengan proses kreatif dalam mewujudkan konsep musik dan lagulagu Sunda dalam rangka sosialisasi visi misi Bandung barat tersebut, penulis mengambil beberapa unsur musikalnya sebagai idiom musikal yang sangat khas. Adapun yang penulis ambil idiom tersebut adalah unsur irama, melodi dan ornamen, tempo, serta teknis vokalisasi. Unsur irama, musik 
dan lagu-lagu visi dan misi Bandung Barat umumnya menggunakan serta mengolah irama tetap. Kemudian unsur melodi merupakan salah satu unsur yang cukup dominan baik yang berkontur mendatar, sedang, dan tinggi. Namun kecenderungan melodi yang diambil dari unsur kawih relatif berjarak jauh serta menggunakan ornamentasi yang relatif sederhana. Ukuran sederhana yang dimaksud salah satunya adalah struktur melodi, tempo, maupun irama tidak menggunakan struktur yang rumit. Hal tersebut dengan harapan isi lirik lagu akan lebih mudah untuk dicerna oleh pendengarnya. Namun demikian, agar karya tersebut dipandang menarik, maka aspek-aspek musikal seperti melodi, irama, maupun tempo yang digunakan mempunyai varias-variasi tertentu, misalnya dalam mengolah tempo lambat, sedang, dan tempo cepat. Hal ini dilakukan untuk mendukung lagu agar tetap dinamis sehingga tidak terkesan monoton. Kemudian satu yang sangat berpengaruh dari bentuk lagu kawih adalah cara pembawaan lagu, umunya lagu-lagu kawih dibawakan melalui teknik suara lebih ekspresif yakni dengan menggunakan teknik suara yang relatif lebih lepas. Artinya, teknik vokal yang digunakan oleh para juru kawih terutama ketika membawakan lirik lagu relatif lebih jelas dalam melafalkan artikulasi dibandingkan dengan juru tembang.

\section{c. Idiom Barat: Musik dan Lagu Pop}

Seperti telah diutarakan di atas, penggarapan lagu-lagu dan musik visi dan misi Bandung Barat di samping bersumber dari lagu dan musik Sunda, juga mengadopsi dari lagu dan musik pop yang berlaku pada saat ini. Yang dimaksud dengan musik dan lagu pop adalah musik yang secara tekstual merupakan sebuah sajian musikal dalam bentuk seni musik dan lagu yang berstruktur musik barat. Artinya dari aspek lagunya mempunyai struktur melodi serta ornamentasi yang berbeda dengan lagu kawih dan tembang Sunda. Salah satu yang menjadi ciri pembedaannya adalah interval yang digunakannya relatif berjarak jauh dalam susunan nada-nadanya. Oleh karena dapat dipahami bahwa produk musik dan lagu pop sangat signifikan dalam rangka pemanfaatan dunia industri, yang lebih mengedepankan selera masyarakatnya, semata-mata untuk kepentingan komersial.

Namun lepas dari hal tersebut, pada kenyataannya bahwa musik dan lagu pop sudah menjadi bagian dari produk kebudayaan kita yang tidak dapat tolak keberadaannya di tengah masyarakat. Oleh karena itu, dalam konteks kreatif, menarik dan menjadi peluang penting untuk mengadopsi beberapa unsur musikal dari musik barat yang ditransformasikan pada musik dan lagu yang bertemakan lirik visi dan misi Bandung Barat. Adapun unsur yang diadopsi dari musik dan lagu pop di antaranya: beat, kontur melodi, serta teknik pembawaan. Unsur beat atau irama terutama dalam aspek musik untuk mengiringi lagu dalam penggarapannya cukup dominan digunakan pada bagian intro, interloude dan coda. Di samping dalam penggarapan aspek lagu, penulis mengadopsi beberapa bagian kontur melodi yang lazim digunakan dalam lagu pop.

\section{Bentuk Penciptaan}

Pada umumnya bentuk seni yang diciptakan oleh seniman, melalui berbagai media ungkapnya bertolak dari kompetensi masing-masing keahlian seniman. Media ungkap tersebut dapat berupa lukisan, lagu, bahasa, gerak, dan sebagainya. Kemudian, bentuk penciptaan seni terwujud melalui sebuah proses kreatif, yang selanjutnya difungsikan sesuai dengan situasi dan kondisinya. Berkaitan dengan hal ini, penulis mewujudkan bentuk penciptaan yang dijadikan media sosialisasi visi dan misi Bandung Barat adalah musik dan lagu. Musik yang di dalamnnya terdiri atas beberapa 
unsur musikal yang disusun sedemikian rupa, sehingga membangun sebuah musikalitas. Adapun unsur-unsur musikal yang dipandang dominan antara lain; melodi, irama, dan tempo. Pengertian ketiga unsur tersebut secara sederhana dapat dijabarkan sebagai berikut; Melodi adalah tinggi rendahnya nada yang disusun dalam suatu frase. Kemudian irama, berkaitan erat panjang pendeknya not dan berat ringannya aksen (tekanan) pada not. Selanjutnya tempo adalah ukuran kecepatan dan lambatnya dalam birama lagu.

Di samping musik, aspek penting lainnya adalah lagu. Adapun yang dimaksud dengan lagu adalah gubahan seni nada atau suara dalam urutan, kombinasi, dan hubungan temporal-biasanya diiringi oleh alat musik-untuk menghasilkan gubahan musik yang mempunyai kesatuan dan kesinambungan (mengandung irama), termasuk ragam nada atau suara berirama yang juga dapat disebut dengan lagu. Musik dan lagu merupakan dua unsur yang selalu harmonis dan saling melengkapi, keduanya identik selalu bersama, maka kedua unsur tersebut tidak dapat dikonstruksi (dalam konteks proses kreatif) secara parsial. Di samping itu, terdapat satu unsur lain yang memiliki signifikansi di antara lagu dan musik, unsur tersebut adalah lirik.

Lirik-lirik lagu yang diciptakan khususnya dalam rangka sosialisasi visi dan misi Kabupaten Bandung Barat, yang bertujuan untuk diapresiasi khususnya oleh masyarakat Bandung Barat agar dimengerti serta dipahami dibuat dengan mengacu pada dinamika dan budaya masyarakat pemiliknya, sehingga proses penciptaan atau pembuatan lirik dalam lagu merupakan ujung tombak dalam proses ini. Selain dari pada itu, pada konteks sosialisasi visi dan misi melalui musik dan lagu, lirik lagu harus dapat dengan mudah dipahmi oleh masyarakatnya. Hal tersebutberdasarkan pengamatanbahwa kecenderungan masyarakat sekarang ketika merespon berbagai informasi tersebut akan lebih pragmatis. Artinya apresiator umum cenderung merspons informasi tersebut didasari adanya daya tarik yang verbal. Melihat kenyataan sekarang dengan maraknya media informasi baik elektronik maupun cetak, dengan berbagai pengkemasannya, langsung ataupun tidak mempengaruhi kebiasaan masyarakat dalam menangkap serta merespon berbagai informasi. Oleh karena, melihat kenyataan seperti ini langkah mengantisipatif dalam mersepon tantangan tersebut penting untuk dijadikan pertimbangan, termasuk dalam mengonstruksi sebuah karya seni. Oleh karena, kecenderungan masyarakat kita saat ini relatif sulit untuk memahami sesuatu pesan khusus dari pemerintah, maka melalui pengkemasan sedemikian rupa menarik diharapkan mereka akan lebih merespon dengan baik.

\section{Musikalitas Lagu Bandung Barat Cermat}

Lagu atau nyanyian merupakan bagian dari sebuah karya musik, yang tentunya memiliki struktur yang terkandung di dalamnya. struktur merupakan rangkaian suatu susunan unsur yang membentuk sebuah karya musik, dalam hal ini lagu. Kekuatan utama pada lagu "Bandung Barat Cermat" terdiri dari dua hal, yakni; lirik/syair, serta lagu dan musikalitas itu sendiri. Dalam konteks lirik, lagu ini jelas memiliki kekuatan verbal yang eksplisit mempropagandakan maksud dari visi-misi instansi, sedangkan teks musikalitas bisa dikaji berdasarkan unsur yang salah satunya adalah melodi. Melodi adalah susunan rangkaian nada (bunyi dengan rangkaian teratur) yang terdengar berurutan serta berirama dan mengungkapkan suatu gagasan pikiran dan perasaan (Jamalus, 1998:16). Melodi adalah naik turunnya harga nada yang bisa disebut sebagai gagasan inti musikal, yang sah menjadi musik bila ditunjang dengan gagasan yang memadukanya dalam 
suatu kerja sama dengan irama, tempo, bentuk dan lain-lain (Ensiklopedi musik, 1992: 28). Dari pengertian-pengertian tersebut dapat disimpulkan bahwa melodi adalah suatu rangkaian nada yang terbentuk dari perubahan-perubahan harga nada dalam kaitannya dengan irama, tempo, bentuk dan sebagainya.

Sebelum menginjak kepada melodi, kita mulai dahulu dari unsur terkecil dari melodi yaitu nada. Di dalam lagu "Bandung Barat Cermat" melodi nya dibangun oleh nadanada yang merupakan tangga nada pentatonis karawitan Sunda, dengan memaksimalkan penggunaan nada nada sisipan yang tedapat di dalamnya (tetapi tidak menggunakan modulasi). Dengan memaksimalkan penggunaan nada sisipan tersebut, kesan yang dihasilkan bahwa lagu tersebut adalah lagu yang terdiri dari diatonic, padahal tidak. Mengapa disebut kesannya seperti diatinos, karena bila didengarkan secara selintas, antara tangga nada karawitan sunda lengkap dengan semua sisipan nya, akan terdengar seperti diatonic bila dibunyilan, walaupun sebenarnya secara teori berbeda.

Pemilihan nada tersebut juga secara tidak langsung merupakan pengaruh dari pencipta lagu yang mempunyai latar belakang kemampuan vokal selain dari vokal di wilayah estetika karawitan sunda.

Kemiripan antara tangga nada pentatonik karawitan sunda dan diatonik dapat digambarkan secara sederhana, seperti terlihat pada tabel 1.

Contoh penggunaan nada pada lagu KBB Cermat pada baris ke 1 dan 2:

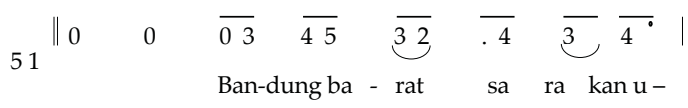

Tabel 1. Perbandingan tangga nada pentatonik Karawitan Sunda dan diantonik

\begin{tabular}{|lllllllll|}
\hline Degung & $\mathrm{da} / 1$ & $\mathrm{mi} / 2$ & $\mathrm{ni} / 3-$ & $\mathrm{na} / 3$ & $\mathrm{ti} / 4$ & $\mathrm{la} / 5$ & $\mathrm{leu} / 5+$ & $\mathrm{da} / 1$ \\
\hline Madenda & $\mathrm{na} / 3$ & $\mathrm{ti} / 4$ & $\mathrm{la} / 5$ & $\mathrm{leu} / 5+$ & $\mathrm{da} / 1$ & $\mathrm{mi} / 2$ & $\mathrm{ni} / 3-$ & $\mathrm{na} / 3$ \\
\hline Diatonic & $\mathrm{do} / 1$ & $\mathrm{si} / 7$ & $\mathrm{lha} / 6$ & $\mathrm{sol} / 5$ & $\mathrm{fa} / 4$ & $\mathrm{mi} / 3$ & $\mathrm{re} / 2$ & $\mathrm{do} / 1$ \\
\hline
\end{tabular}

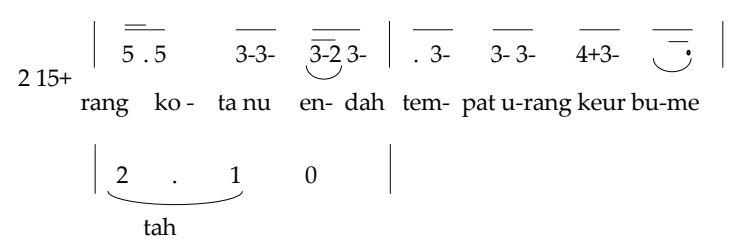

Pada notasi di atas dapat di lihat penggunaan tangga nada pentatonis karawitan Sunda lengkap dengan sisipannya. Meskipun kecenderungannya Madenda, namun nada sisipan membiaskan entitas laras pentatonis tersebut.

Lagu kabupaten "Bandung Barat Cermat" merupakan sebuah lagu propaganda, sifatnya mengajak atau mengkampanyekan sesuatu. Untuk itu penggunaan atau pemilihan nada, penggunaan harga nada cenderung sederhana (rata-rata 1/2), dan penyusunan melodi pun dibuat semudah serta seakrab mungkin dengan pendengar. Dalam penyusunan melodi pun, representasi pengalaman pencipta lagu sangat terlihat di sana. Bila kita perhatikan pada melodi lagu KBB Cermat perpaduan antara unsur pop dan unsur estetika lagu sunda sangat terlihat. Contohnya pada penggalan lagu KBB Cermat di bawah ini:

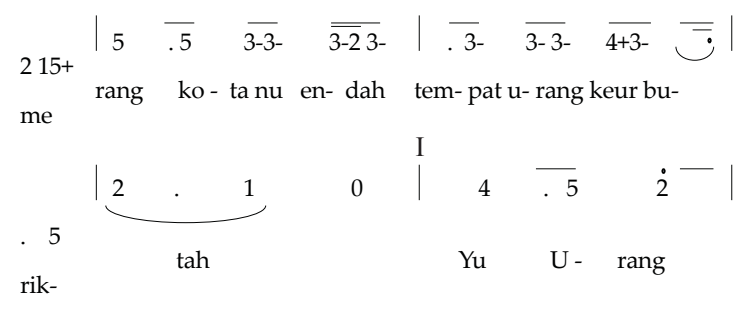

Melodi "kota nu endah", Tampak sekali di luar dari estetika lagu Sunda, dan melodi "tempat urang keur bumetah" melodi tersebut sangat akrab dengan estetika lagu Sunda, baik pada kawih maupun tembang Sunda. Di sini terlihat jelas salah satu perpaduan dua estetika bernyanyi yang berbeda namun dapat terjalin dalam satu lagu atau dapat dikatakan harmonisasi dua esteika vokal yang berbeda. 


\section{PENUTUP}

Proses artikulasi ide, dari yang berbentuk ideal menuju bentuk riil merupakan sebuah proses biasa dalam sebuah penciptaan sebuah karya. Hal tersebut sebagaimana lazimnya seorang seniman melakukan perenungan dan mengeksplorasi sebuah gagasan untuk dijadikan sebuah karya. Menjadi tidak biasa ketika proses tersebut harus sesuai dengan rambu-rambu dan tatanan formal yang berlaku pada sebuah kebudayaan. Terlebih, yang ideal tersebut sudah terangkum dalam bentuk visi-visi, pada sisi tertentu batasan karya semakin dapat difokuskan namun pada sisi lain tantangan kreativitas semakin menantang karena kreator tidak dibebaskan dalam mengekspresikan gagasan subjektifnya secara menyeluruh. Proses penciptaan lagu yang berdasarkan pada gagasan visimisi ini dikonstruksi tidak hanya untuk menemukan bentuk indah dalam sebuah karya seni (karawitan), namun tantangan lainnya mengharuskan penulis untuk menjadikannya karya yang operasional, menjadi sebuah ide bersama dalam kesadaran masyarakat yang ditujunya. Proses kreatif merupakan dimensi yang terdiri atas; karya itu sendiri, ide/gagasan karya, serta latar belakang referensial atau pengalaman apresiasi seniman kreator. Karya lagu "Bandung Barat Cermat" merupakan representasi dari ide/gagasan yang sekaligus tantangan dan tuntutan karya, yang bertemu dengan pengalaman apresiasi kreator seniman, sehingga di dalam karya tersebut hidup ideom-ideom kekhasan atau identitas pengarangnya.

Dalam karya "Bandung Barat Cermat", identitas kekaryaan yang merepresentasikan latarbelakang kreator eksis dalam unsur mikro musikal, hal tersebut bisa ditunjukan dalam analisis teks lagu, terutama idiom dari Tembang Sunda Cianjuran. Di samping itu, pengalaman referensial tentang musik barat memberikan corak tersendiri sebagaimana nada (laras) dalam lagu "Bandung Barat Cermat" yang dalam beberapa frase terdapat dimensi di mana diferensiasi antara nada pentatonis dan diatonis bias. Berdasarkan seluruh penjabaran tentang karya dan subjek kreator, pada titik ini teori kreatifitas tentang "tekanan", "proses", "pribadi", dan "produk" koheren dan relevan sebagai teori dan pada prakteknya keempat unsur tersebut tidak dapat dipisahkan dalam proses kreatif setiap seniman itu sendiri.

\section{Daftar Pustaka}

Bodiono MA

2005 Kamus Ilmiah Populer. Surabaya: Karya Harapan.

Geger Riyanto

2009 Peter L. Berger: Perspektif Metateori Pemikiran. Jakarta: LP3ES.

Jakob Sumardjo

2000 Filsafat Seni. Bandung: ITB.

Johannes Supriono

2005 Pradigma Kultural Masyarakat Durkhemian, dalam Teori-teori Budaya. Editor Musdji Sutrisno \& Hendar Putranto. Yogyakarta: Kanisius.

Luckmann, Thomas \& Peter L. Berger

2013 Tafsir Sosial atas Kenyataan: Risalah Tentang Sosiologi Pengetahuan. Terj. Hasan Basri. Jakarta: LP3ES.

Utami Munandar

1999 Kreativitas \& Keterbakatan: Strategi Mewujudkan Potensi Kreatif dan Bakat. Jakarta: Gramedia Pustaka Utama. 